\title{
Relating Union Density to Wealth Inequality and Subjective Well-Being Across 13 OECD Countries
}

\section{Erik Meurrens \\ University of Florida}

Faculty Mentor: Anne Donnelly, Center for Undergraduate Research

\begin{abstract}
Since the 1980s, the labor union density has gradually declined across member countries of the Organization for Economic Co-operation and Development (OECD), indicating a lowering percentage of employees represented by unions. In the United States, the declining union density has been shown to have an impact on wealth inequality, which has increased correspondingly. With a lack of representation by labor unions, workers are less secure in their jobs, which could cause a reduction in job satisfaction and an increase in stress. Therefore, a declining union density can also influence the subjective well-being of an impacted group. The aim of this research was to identify and investigate the potential relationships between union density and wage inequality and union density and subjective well-being across thirteen countries through regression analysis. The thirteen countries selected were all developed democracies and members of the OECD. Simple linear regressions were made using the most recent national data for union density, wealth inequality, and subjective well-being. Regression analysis was performed on the most recent data points of the countries as a group, and for each country individually over a period of time. There was a moderate-strong, negative correlation $(R=-0.608)$ for the regression of wealth inequality versus union density, yet inconsistent correlation coefficients between countries individually. There was a moderate-weak, positive correlation $(\mathrm{R}=0.353)$ for the regression of subjective well-being versus union density, with some inconsistent correlation coefficients between countries individually.
\end{abstract}

Keywords: sociology, social science, union density, wealth inequality, well-being

\section{Introduction}

Since the 1980s, the labor share, or the amount of GDP paid out in wages, salaries, and benefits, has declined in a number of member countries in the Organization for Economic Cooperation and Development (OECD), notably the United States, raising concerns about slowing income growth, inequality, and loss of consumer purchasing power (Bental \& Demougin, 2010; Manyika et al., 2019). Likewise, union density in those countries has been declining gradually in recent decades, indicating a lowering percentage of employees represented by labor unions (ChangHwan \& Sakamoto, 2010; Farber \& Western, 2001; Kollmeyer \& Peters, 2019; "Labor Unions," 2018). 
Labor unions are organizations that seek to protect the collective workers they represent, typically comprising workers in a specific industry or field. Unions try to improve their workers' labor conditions through collective bargaining, the process by which labor-represented workers negotiate with their employers, covering aspects such as working hours, training requirements, health and safety, employee rights and responsibilities, wages, benefits, and other forms of employee compensation (Hooghe \& Oser, 2016; "Labor Unions," 2018). Despite this, according to data from the OECD and the U.S. Bureau of Labor Statistics, labor union membership has been steadily decreasing for several decades. In the United States alone, the union density has decreased to a low of $10.5 \%$ of salaried workers as of 2018 . The continued existence of labor unions has been the subject of debate as well. Opponents to labor unions claim that they restrict economic growth by artificially supporting wage growth, increasing operational costs for businesses, and resisting market forces ("Labor Unions," 2018; Legree et al., 2017). Conversely, proponents to labor unions contend that unions provide an essential voice for workers and can be effective at addressing income equality, raising wages, negotiating improved benefits, and regulating working conditions and safety standards ("Labor Unions," 2018; Legree et al., 2017).

\section{Potential Causes for the Decline of Labor Unions}

The ongoing decline of the labor union density in the past decades is complex and has been attributed to various factors by researchers and scholars. In the United States, the beginning of the current trend of declining union membership was influenced by high inflation, global competition and decreasing exports, soaring energy prices, and operational cost increases for businesses employing well-paid, unionized workers, all of which hurt the U.S. manufacturing sector in the 1970s, contributing to economic uncertainty ("Labor Unions," 2018). The federal government responded by deregulating the industrial sector and the private sector, ultimately hurting labor unions' ability to pressure the government (Farber \& Western, 2002; "Labor Unions," 2018). Many scholars attribute the later Reagan administration to exacerbating the already declining U.S. union density throughout the 1980s. During this period, the annual number of union elections fell by $50 \%$, attributed to an unfavorable political climate created by the Reagan administration, characterized by the 1981 Professional Air Traffic Controllers Organization strike which strengthened employers' rights to oppose union organizing, and the appointment of two Reagan appointments to the National Labor Relations Board, which raised the costs of unionization (Farber \& Western, 2002). Unions thus found themselves vulnerable to 
attack by employers' hostile, anti-union tactics, by the anti-union Reagan administration, as well as by labor legislation that had negative implications for the labor movement (Kristal \& Cohen, 2017).

Despite the animosity faced by American unions in the 1980s, these events do not fully explain the continuing decline in union density following that period, or the international trend of union decline in comparable OECD countries during that period. For instance, trade union membership and density had also declined throughout much of Europe during the 1980s, and continues to do so today (Waddington, 2015). One such explanation is that most of the decline in union membership rate is a result of differential employment growth rates, in part due to larger market and regulatory forces causing the increasing nonunion privatization of all sectors of the economy and the reduction in the size of unionized market sectors (ChangHwan \& Sakamoto, 2010; Farber \& Western, 2001; Legree et al., 2017). This disproportionate growth of nonunionized sectors to unionized sectors is likely caused by multiple factors. One such factor is the decline of the manufacturing sector, which substantially contributed to the union density of the United States and comparable OECD countries, as a result of the replacement of labor with capital through automation, globalization, and offshoring of manufacturing jobs, allowing nonunionized branches of the service-based economy to grow (Kristal \& Cohen, 2017; "Labor Unions," 2018; Manyika et al., 2019). Additionally, the financialization of global markets has also contributed to declining union densities by emphasizing the reduction of labor costs and distribution of cost savings back to financial stakeholders (Kollmeyer \& Peters, 2019). This is further exacerbated by the growth of large, multinational firms reaping rising shares of profit over smaller businesses and by those firms being able to attract governments' attention toward their preferences over those of the general public and the dwindling collective voices of union workers (Keister et al., 2015; Manyika et al., 2019).

\section{Labor Unions and Income Inequality}

Alongside the ongoing decline of labor union density is a corresponding gradual increase in income inequality since the 1980s. Countries exhibiting particularly dramatic declines in union density also experienced the largest increases in inequality (Legree et al., 2017). Likewise, labor's share in national income has been decreasing in most OECD countries since the 1980s despite output in the industrial world growing significantly, raising concerns about slowing income growth, inequality, and loss of consumer purchasing power (Bental \& Demougin, 2010; 
Manyika et al., 2019). Literature on the topic reinforces the idea that declining labor union density has contributed to rising income and wage inequality. Empirical studies have found that union decline is central to and explains up to half of the rise of inequality since the 1970s, controlling for relative skills, relative education, and demographic variables of race and gender (ChangHwan \& Sakamoto, 2010; Hu \& Hanink, 2018; Kristal \& Cohen, 2017; Legree et al., 2017; VanHeuvelen, 2018; Wilmers, 2017).

One such explanation of this trend focuses largely on the rising power of companies in relation to workers, explaining that the deterioration of labor unions disempowers workers and workers' ability to act collectively and apply pressure to achieve wage growth (Kristal \& Cohen, 2017; Manyika et al., 2019). However, another explanation regarding the rise in income inequality and lack of wage growth contends that this phenomenon is a product of market forces such as globalization and increased competition as well as computerization and an increase in skilled labor (Kristal \& Cohen, 2017; Wilmers, 2017). While findings suggest that these factors do play a significant role, the increase in wage dispersion cannot be fully explained by market forces and skill-biased technological change (ChangHwan \& Sakamoto, 2010). Most sociologists and political scientists, as well as some economists, tend to emphasize pay-setting institutional changes, such as declining union density and wage stagnation, as driving inequality and question the idea that the market is the main explanation for rising inequality (Kristal \& Cohen, 2017; Wilmers, 2017). This is further supported by current research in the relationship between unions and income inequality as the pathways linking unions and wage inequality are robust in the studies that have examined them, and union density is generally associated with higher wages, less wage inequality, and a higher labor share (VanHeuvelen, 2018; Wilmers, 2017). Moreover, data from long-running longitudinal studies in the U.S. support the idea that both union membership and unionization increased wage premiums and compressed wage distributions, thereby reducing wage inequality (VanHeuvelen, 2018).

\section{Labor Unions and Well-Being and Health}

The consequences of growing wealth inequality limits the access of lower-class workers away from advantageous neighborhoods and schools, it limits their prospects of home ownership, it limits their access to private-safety nets to be able to take risks like going to college or having insurance, and it can have potential psychological effects like increased stress (Keister et al., 2015). These consequences can have a potentially harmful effect on an individual's well- 
being. Thus, given that union density is a contributing factor to increases in inequality, union density could be related to one's subjective well-being.

The limited volume of the literature examining the relationship between labor unions and well-being suggests that unions increase the life satisfaction of citizens, and thus impacts their subjective well-being (Flavin et al., 2010; Radcliff, 2005). This is likely due to labor union's effect on job and wage security, with labor unions advocating for greater wages and occupational rewards as well as improved working conditions, which corresponds to greater employee satisfaction at work (Flavin et al., 2010; Tziner, 1983). Findings also suggest that this effect on life satisfaction holds for nonunion members as well due to the effects of collective bargaining agreements spreading into nonunionized occupations, potentially as a result of employers trying to be attractive in the labor pool relative to their unionized counterparts (Eisenberg-Guyot et al., 2020; Flavin et al., 2010). However, the ongoing decline in union density undermines workers' power over wages and working conditions especially those that of lower income workers (Eisenberg-Guyot et al., 2020; Flavin et al., 2010). Many studies have attributed union decline to affecting the general socioeconomic conditions, such as work satisfaction and health, in a country, and that union decline influences rising economic volatility within workers' careers (VanHeuvelen, 2018). Union decline has also allowed for greater corporate control over retirement for these workers, resulting in less economic security during retirement (Estes \& Dicarlo, 2019). It is possible that this decrease in economic security manifests as a lowering in job satisfaction and a psychological and health toll to the worker throughout their lives.

Additionally, labor union density appears to have an observable effect on mental health. Countries with higher labor union density were shown to have lesser rates of depressive symptoms, irrespective of individual union status (Reynolds \& Buffel, 2020). One reason for this may be due to the impact unions have on life and work satisfaction, but another hypothesis suggests that unions may reduce alienation from workers' labor and their co-workers by giving union members a collective way to arrange how workplaces are run (Flavin et al., 2010). With decreases in union density, alienating work increases, thus imposing psychological costs on people that contribute to depression, job dissatisfaction, and a general decline in life satisfaction (Flavin et al., 2010). In essence, labor unions act as a social support network for workers, protecting them against the consequences of stress by providing a forum to voice their concerns and by improving economic security (Flavin et al., 2010; VanHeuvelen, 2018). 
In addition to mental health, declining union rates have also been shown to correlate with mortality. Over the last several decades, life expectancy in the United States has stagnated or declined for lower-classes relative to upper classes, mainly due to an increase in fatal-overdose and suicide rates across all racial groups, indicating that growing income inequities have affected this trend. A correlation found that, overall, a $10 \%$ increase in union density was associated with a $17 \%$ relative decrease in overdose/mortality (Eisenberg-Guyot et al., 2020). The reason labor unions have this relationship may be due in part to how they decrease rates of depressive symptoms, by decreasing alienation, providing economic security, and by providing protection from material deprivation, occupational hazards, and stressors (Eisenberg-Guyot et al., 2020; Estes \& Dicarlo, 2019; Flavin et al., 2010; Radcliff, 2005; Reynolds \& Buffel, 2020).

\section{Current Study}

The purpose of the current study is to investigate the relationship between union density and wealth inequality and subjective well-being by utilizing simple linear regressions to assess the strength of the correlation between the variables. Despite the relationship between wealth inequality and union density being investigated by studies in the past, those studies focused mainly on the United States. This paper aims to see whether this relationship is as strong among twelve other developed countries by looking at the correlation between union density and wealth inequality within those countries individually and whether this relationship is noticeable by examining the most recent reported national data. Additionally, this data will be used to assess if there is an observable relationship between union density and wealth inequality internationally. Moreover, despite current literature supporting the idea that union density appears to have some effect on workers' job satisfaction and health, few have investigated the relationship between union density and subjective well-being. Thus, in addition to wealth inequality, this paper seeks to identify and assess the strength of the correlation between subjective well-being and union density in order to investigate the potential for a relationship between the two variables among multiple countries. By doing so, this paper will contribute to the relatively small volume of literature on the relationship between union density and well-being and act as a foundation to support future investigations into that relationship. Based on the literature review, the research hypotheses expect that there exists a negative correlation between wealth inequality and union density, and that there is a positive correlation between subjective well-being and union density among the selected countries. 


\section{Materials and Methods}

This paper investigates the relationship between union density and wealth inequality and subjective well-being in thirteen industrialized democracies by aggregating data from reliable data sets and reports and identifying correlations between the variables through regression analysis. The thirteen countries examined for this study are Australia, Canada, Finland, France, Germany, Italy, the Netherlands, Norway, Spain, Sweden, Switzerland, the United Kingdom, and the United States. These countries were chosen due to their similar forms of government and similar economies. Additionally, the countries are all a part of the Organization for Economic Co-operation and Development (OECD) and were used in the referenced studies of this paper.

The most recent data sets and reports from the World Bank, OECD, and the World Happiness Report were analyzed in this paper. The union density data representing the percentage of the population of each country that is part of a union were obtained from the OECD; additional data were needed from the U.S. Bureau of Labor Statistics (BLS) to supplement data for the United States. These data were collected by the OECD and the BLS from survey and government data. Wealth inequality data were obtained from the World Bank according to the Gini index for inequality, with higher indices representing greater inequality within the respective country. These data were collected by the World Bank based on primary household survey data obtained from government statistical agencies and World Bank country departments. Data measuring the subjective well-being for each country were utilized from aggregate data from the World Happiness Report's ranked indices of subjective well-being, with a higher index indicating greater happiness. The data are available for public use online.

Regression analysis was done on the data to determine the correlation coefficient $(\mathrm{R})$ between union density and each of the two dependent variables - wealth inequality and subjective well-being. The data were then processed using Excel and compiled into tables to create simple linear regressions for each country using plotted data between union density and wealth inequality, and union density and subjective well-being. The correlation coefficients were then recorded. Additionally, using the most recent data pairs for each country, linear regressions were calculated for union density and wealth inequality and subjective well-being to assess the relationship, among all countries, between the union density and each of the other two variables. Afterwards, the correlation coefficients produced were analyzed to determine the relationship of the variables. 


\section{Union Density and Wealth Inequality}

\section{Results}

Linear regressions were first created using the most recent data point of union density and wealth inequality per each of the 13 countries analyzed to assess the strength and direction of the correlation between the two variables among all countries. By creating a simple linear regression, a moderate, negative correlation $(R=-0.608)$ was determined between wealth inequality and union density among the countries' most recent data points, as shown in Figure 1.

\section{Figure 1}

Wealth Inequality vs. Union Density as Observed Between the Most Recent Data Point of Each Country

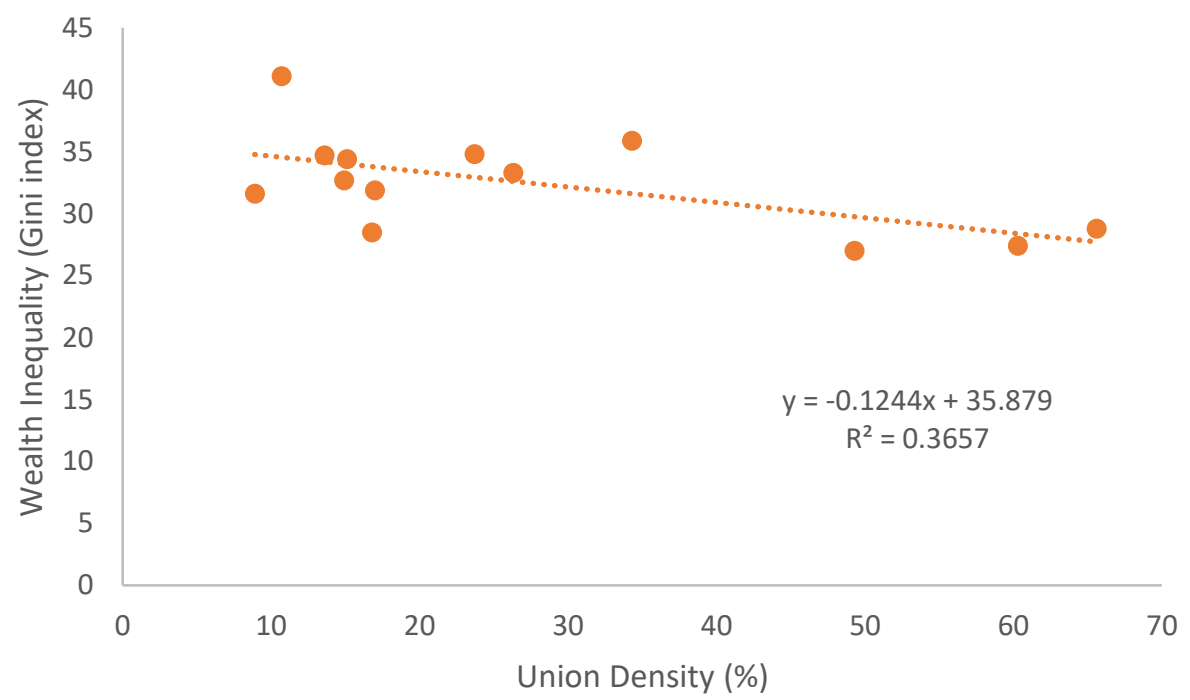

Linear regressions were then created for each country individually using each country's past union density and wealth inequality data. The respective correlation coefficients were then recorded. As shown in Figure 2, there appeared to be considerable inconsistencies between the correlations of each country. 


\section{Figure 2}

Correlation Coefficients of Wealth Inequality vs. Union Density for Each Country Individually

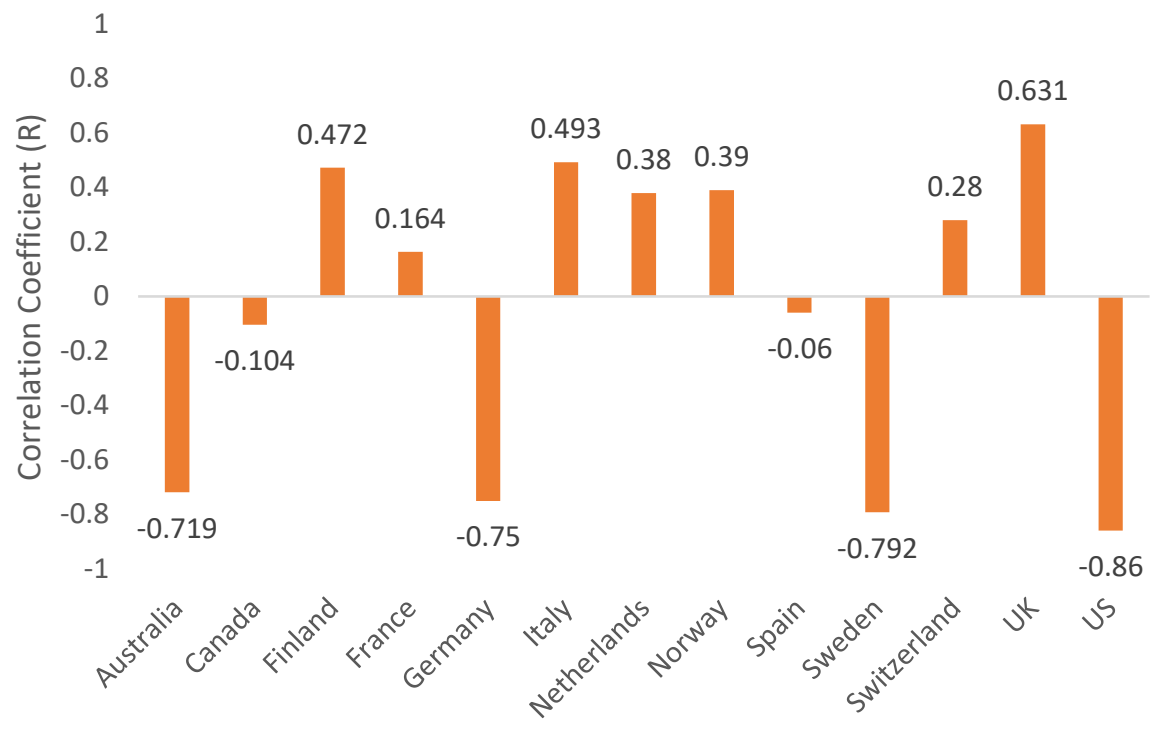

\section{Union Density and Subjective Well-Being}

Like with wealth inequality, simple linear regressions were made to examine the relationship between union density and well-being. A regression was made using the most recent data point for union density and well-being per each of the 13 countries and then plotted to assess the correlation. The simple linear regression indicated a moderate-weak, positive correlation $(\mathrm{R}=0.353)$ between wealth inequality and union density, as shown in Figure 3.

\section{Figure 3}

Subjective Well-Being vs. Union Density as Observed Between the Most Recent Data Point of Each Country

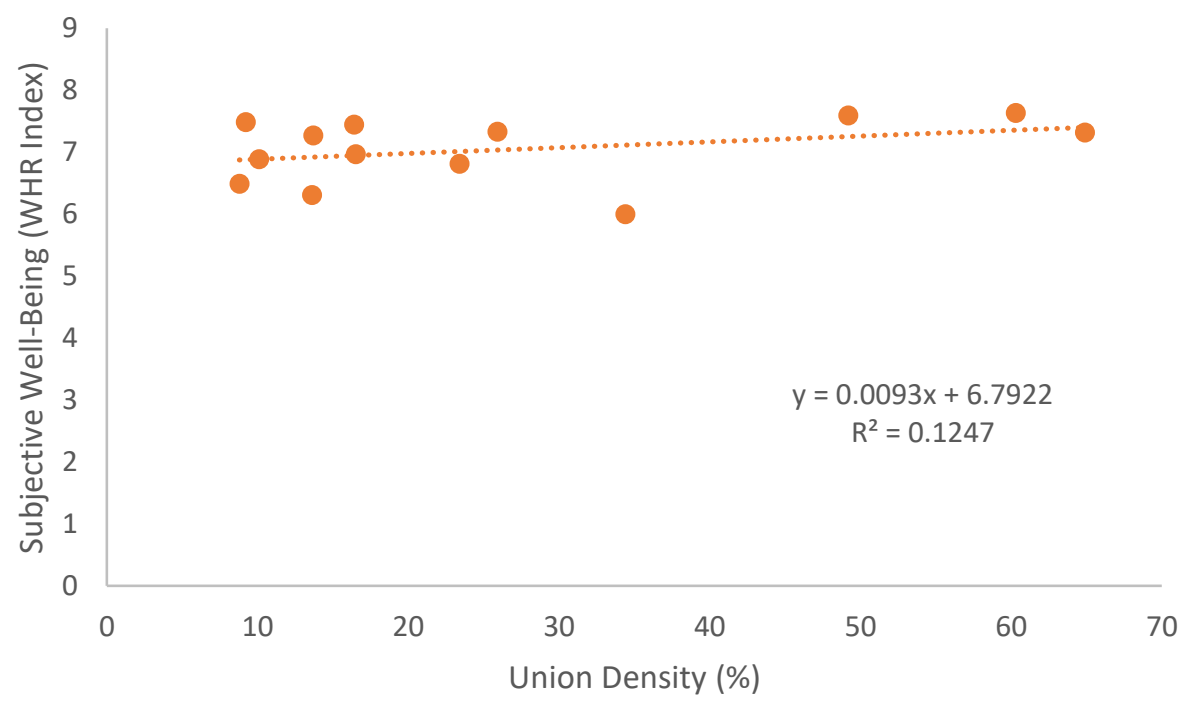


Linear regressions were then created individually for each country using each country's past union density and well-being data. The correlation coefficients were then recorded. Compared to union density and wealth inequality, results showed many more consistent positive correlations when comparing each country as demonstrated in Figure 4.

\section{Figure 4}

Correlation Coefficients of Subjective Well-Being vs. Union Density for Each Country Individually

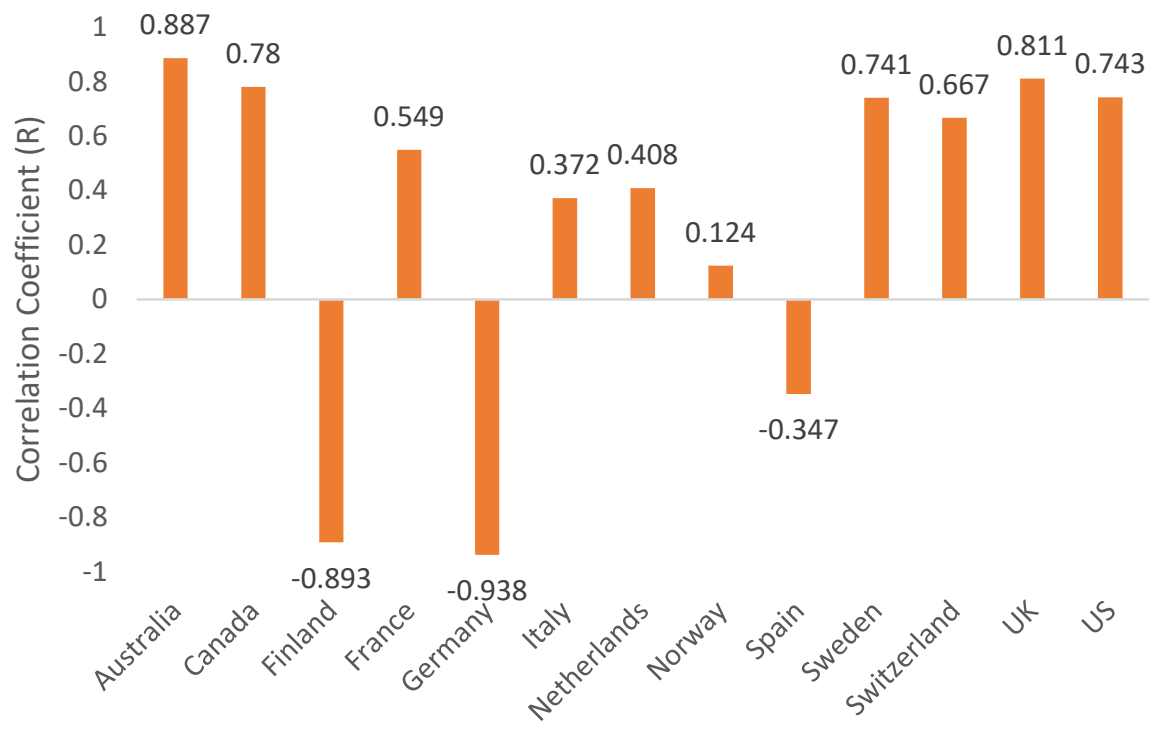

\section{Discussion}

While the relationship between union density and wealth inequality has been studied extensively as it pertains to the United States, the relationship between those two variables as it pertains to other developed countries has not been thoroughly investigated. This paper aimed to identify if this relationship could be discerned among other developed democracies. By examining countries' most recent union density and wealth inequality figures, the results demonstrated a moderate-strong, negative correlation between the two variables overall; countries with higher inequality figures tended to have lower union densities. However, when viewing the relationship between the variables over time in each country individually, this relationship was widely inconsistent between the countries, indicating that perhaps some other factors may be involved and that the issue is more complex. Moreover, the association between union density and subjective well-being was investigated due to a lack of literature examining 
the relationship. Performing regression analysis on the data revealed a moderate-weak, positive correlation between the two variables overall, and examining the correlations for each country individually revealed somewhat more consistency in the relationship between the two variables as it pertains to the sign of the correlation coefficient for each country. The findings support the research hypotheses, yet the individual correlation coefficients of each country qualified both hypotheses as some country-specific coefficients were inverse from what was expected, signifying that perhaps other factors are involved.

\section{Conclusion}

Overall, countries with greater union densities tended to have lower wealth inequality and marginally greater levels of subjective well-being, supporting the research hypotheses. However, observing the correlations between union density and wealth inequality and subjective wellbeing within each individual country revealed inconsistent relationships. Future research needs to be done to explore these relationships and explain the inconsistencies in the data, especially with regards to the trends within countries that did not conform to the hypotheses.

\section{References}

Bental, B., \& Demougin, D. (2010). Declining labor shares and bargaining power: An institutional explanation. Journal of Macroeconomics, 32(1), 443-456. https://doi.org/https://doi.org/10.1016/j.jmacro.2009.09.005

ChangHwan, K., \& Sakamoto, A. (2010). Assessing the consequences of declining unionization and public-sector employment: A density- function decomposition of rising inequality from 1983 to 2005. Work \& Occupations, 37(2), 119-161. https://doi.org/10.1177/0730888410364938

Eisenberg-Guyot, J., Mooney, S. J., Hagopian, A., Barrington, W. E., \& Hajat, A. (2020). Solidarity and disparity: Declining labor union density and changing racial and educational mortality inequities in the United States. American Journal of Industrial Medicine, 63(3), 218-231. https://doi.org/https://doi.org/10.1002/ajim.23081

Estes, C. L., \& Dicarlo, N. B. (2019). The right to work and the right to retire: A political economy perspective on precarity: Corporate control of the labor market has led to older workers' loss of economic security and opportunity. Generations, 43(3), 29-34.

Farber, H. S., \& Western, B. (2001). Accounting for the decline of unions in the private sector 1973-1998. Journal of Labor Research, 22(3), 459-485.

Farber, H. S., \& Western, B. (2002). Ronald Reagan and the politics of declining union organization. British Journal of Industrial Relations, 40(3), 385-401. https://doi.org/https://doi.org/10.1111/1467-8543.00240 
Flavin, P., Pacek, A., \& Radcliff, B. (2010). Labor unions and life satisfaction: Evidence from new data. Social Indicators Research, 98(3), 435-449. https://doi.org/10.1007/s11205-009-9549-z

Hooghe, M., \& Oser, J. (2016). Trade union density and social expenditure: A longitudinal analysis of policy feedback effects in OECD countries, 1980-2010. Journal of European Public Policy, 23(10), 1520-1542. https://doi.org/10.1080/13501763.2015.1102952

Hu, Q., \& Hanink, D. M. (2018). Declining union contract coverage and increasing income inequality in U.S. metropolitan areas. Professional Geographer, 70(3), 453-462. https://doi.org/10.1080/00330124.2017.1416298

Keister, L., Zucman, G., Shapiro, T., Pfeffer, F., Bartels, L., Sherraden, M., Kopczuk, W., \& Scheve, K. (2015). Rising wealth inequality: Causes, consequences and potential responses. University of Michigan.

Kollmeyer, C., \& Peters, J. (2019). Financialization and the decline of organized labor: A study of 18 advanced capitalist countries, 1970-2012. Social Forces, 98(1), 1-30.

https://doi.org/10.1093/sf/soy105

Kristal, T., \& Cohen, Y. (2017). The causes of rising wage inequality: The race between institutions and technology. Socio-Economic Review, 15(1), 187-212. https://doi.org/10.1093/ser/mww006

Labor Unions. (2018). In. Gale Opposing Viewpoints Collection. Gale.

Legree, S., Schirle, T., \& Skuterud, M. (2017). The effect of labor relations laws on unionization rates within the labor force: Evidence from the Canadian provinces. Industrial Relations, 56(4), 605639. https://doi.org/10.1111/irel.12187

Manyika, J., Mischke, J., Bughin, J., Woetzel, J., Krishnan, M., \& Cudre, S. (2019). A new look at the declining labor share of income in the United States. In: McKinsey Global Institute.

Radcliff, B. (2005). Class organization and subjective well-being: A cross-national analysis. Social Forces, 84(1), 509-526. https://doi.org/10.1353/sof.2005.0118

Reynolds, M. M., \& Buffel, V. (2020). Organized labor and depression in Europe: Making power explicit in the political economy of health. Journal of Health \& Social Behavior, 61(3), 342-358. https://doi.org/10.1177/0022146520945047

Tziner, A. (1983). Correspondence between occupational rewards and occupational needs and work satisfaction: A canonical redundancy analysis. Journal of Occupational Psychology, 56(1), 49-56. https://doi.org/10.1111/j.2044-8325.1983.tb00109.x

VanHeuvelen, T. (2018). Moral economies or hidden talents? A longitudinal analysis of union decline and wage inequality, 1973-2015. Social Forces, 97(2), 495-530. https://doi.org/10.1093/sf/soy045

Waddington, J. (2015). Trade union membership retention in Europe: The challenge of difficult times. European Journal of Industrial Relations, 21(3), 205-221. https://doi.org/10.1177/0959680114538708

Wilmers, N. (2017). Labor unions as activist organizations: A union power approach to estimating union wage effects. Social Forces, 95(4), 1451-1477. https://doi.org/10.1093/sf/sow108 